\title{
Translation, Ideology and Gender
}

Camus, Camus, Carmen.; Christina Gomez Castro.; and Julia T. WiLliams CAMUS. (eds.). 2017. Translation, Ideology and Gender. Newcastle: Cambridge Scholars Publishing.

Reviewed by ATHIRA M.

Gender in translation is an area that has been discussed and debated for a long period and has spawned theories by translation experts like Sherry Simon and Susan Bassnett. Translation being a practice that strives to bring a sense of equivalence, gender and ideology are detrimental to be discussed in the field.

The work Translation, Ideology and Gender is a compilation of nine essays, arranged in three sections, namely, Translation, Ideology and Gender in Health Sciences, Translation, Ideology and Gender in Narrative and Poetry and Translation, Ideology and Gender Policies and identity issues. The book is jointly edited by Carmen Camus Camus, Cristina Gomez Castro and Julia T. Williams Camus. The book opens with the introductory essay, Breaking New Ground, with a quote from Gideon Toury, the famous translation scholar:

"The novelty of an entity derives from the target culture itself and relates to what that culture is willing to accept vs. What it feels obliged to submit to modification, or even totally reject" (p. 1).

The choice of this particular quote suits the content of this book of essays, for rather than hinting at the cultural turn of translation, the book is an answer for the number of questions pertaining to the female and the activity of translation. Ranging from the contribution of women translators to how 
Athira M.

translation can possibly make a better turn for many women of peripheral existences, the book covers a wide range of topics.

Slightly humorous and equally alarming fact to be found, being reflected in these essays, explains the presence of female translators during times when female authorship was being frowned upon. Since translation was relegated to a secondary activity that entails not much intellect, women could easily find a place in that. This fact comes very close to Venuti's theory of translation being an invisible activity (Venuti 1995).

Part one deals with translation, ideology and gender in the field of health sciences. The essay, Gender Biases in Medical Textbooks, makes an intriguing read for it brings to light certain half hidden truths about scientific language which is generally supposed to be neutral (p. 19). The neutrality of language remains a myth and every language is culturally loaded. Italian medical text books are taken for a study and the language is found to be vividly anthropocentric. In the case of translations, gender neutral language of the source texts is found to be turned into sexist language in the translations. The visual aspect of translation is also discussed where the male body is being presented as the standard and female body an aberration of the norm. In the rare instances where female body was portrayed, they were shockingly images of women in pin-up girl poses as well as nude poses, whereas the photographs of men had the models' faces hidden.

Third essay looks into how economic and linguistic barriers deprive most Amazigh women of adequate health care (p. 43). Cultural roots of Amazighs, an indigenous group in Morocco is brought into the light. The Arabic subverting the local Amazigh language, the locals are unable to articulate their health problems. Morocco being a multilingual society where all languages do not enjoy the same political and social status, 
the essay points out to a major problem. It serves as a reminder to preserve the native language varieties.

Part two is about narrative and poetry translation. The fourth essay, Simone de Beauvoir: Censorship and Reception Under Francoism, is a study of the society of Francoist Spain where women were treated as secondary citizens (p. 75). The essay can be better appreciated with a historical and cultural knowledge of the Spain of those times. Simone de Beauvoir's Le Deuxieme Sexe was translated into Catalan first, owing to the limitation of the potential readership. Church's reaction to the work was nothing short of a backlash, for having glorified female adultery and as a result, the work had to endure number of revisions and edits, before it was finally published. The entire translation journey is full of hurdles that points to the strict censorship of the day, which made translation a veritably difficult process.

The fifth essay, Rewriting and Sexual (self) Censorship in the Translation of a Canadian Novel, is perhaps one of the finest essays in the volume (94). It brings up the ideas of structural and implicit censorship. Margaret Laurence's novels are taken up for study, in particular, A Jest of God, translated into Spanish by Agustin Gil Lasierra. The essay talks in detail of how the translation gives insight into the moral fabric of Spain at the time and also, the translator's sexual morality. Scenes of explicit sex were deleted, including the ones where the female protagonist expresses her desire for her man, which is dubbed as "woman obsessed by masculine attraction" (p. 101). The portion dealing with the narrator's concept of virginity as something precious being laughable and nauseating, is omitted. Also, interesting to note is how the translator has managed to overcome the shackles of the imposed censorship by inserting suspension dots, or textual silence. 
Athira M.

The sixth essay, Women's Sickness in Literature: The Use of Poisons in Novels explains the use of poison in novel Madame Bovary by Flaubert and Agatha Christie's short story, The Thumb Mark of St. Peter (p. 113). Not a brilliantly crafted essay, it merely talks about how powerfully the passages are written in the above narratives. It does not appear to have to do much with translation.

The seventh essay, Poetry Translation during Postwar Spain, looks at women as poets and translators during postwar Spain (p. 123). It talks about how women had to face a double censorship. Only topics for them were love, religion and spirituality. Women characters in mainstream narratives and poetry were the passive objects of male desire. The female poets of the age, not just fought against this objectification, but also against the society. They fought against the terminology, poetisa (poetess) that distinguished them from the mainstream poeta (poet), thus keeping male and female poetry separate (p. 129). Interestingly, forty percent of translators were women, the reason being the low status denoted to the translator's job, or in other words, translator's invisibility (Venuti 1995).

The eighth essay, Context Matters: Feminist Translation between Ethics and Politics in Europe, largely deals with how translation brings exchange of culture and ideas in a transnational and multi-lingual space like that of Europe (p. 143). The essay makes an interesting read, but for certain lapses like the sentence, "Turkey, which we know is not so open to feminist issues" (p. 148), which is a problematic usage by the author, for it reflects a bias, encourages a stereotype. It powerfully discusses how a feminist translator should be aware of the "positionality" of women, "situated knowledge" (acknowledgement of the position of the writer, her racial, geo political positions) (p. 150). It goes on to state how a feminist translator attains an authority over the source text. Fidelity and 
transparency are treated to be less important factors, where experimentation and relativity take their place. Translation, especially when talked in a multicultural space like Europe, becomes a "heteroglossic, multivoiced practice, a social act for which the translator is responsible and through which s/he becomes a cultural agent" (p. 150).

Chapter nine, Construction of identity in magazines aimed at women, brings up an issue discussed a lot, nevertheless argues it out beautifully (p. 166). The essay discusses how some voices are heard all over the world, while others remain unheard. Focused on the printed magazines aimed at women in Spain, the essay brings to light issues like the imperialism of English language and the ethics of the advertising sector. The essay takes up a comparative analysis of two women's magazines, Cosmopolitan and Telva. Irrespective of ideological and target readership differences, the two magazines use language in similar fashion. Language is thus remarkably put together in the essay, as it states that the use of language is never neutral or innocent, each communicative act is intentional and it takes place immersed in asymmetric power relationships" (p. 169).

The essay makes use of concepts developed by Barthes that of myth, first order signification (disguise) and second order signification (real ideology) to explain how the magazines work out their ideology. In the case of the magazines, the creators present the myth, first, come up with an ideology disguised as "normal" whereas the real ideology gets imbibed by the readers.

The essays in this collection are gleaned from a variety of areas and are logically structured. They give an insight into how politics, location, ideology and gender are related organically. 
Athira M.

The work remains to be a must read for researchers and students interested in gender and translation, for it covers a wide range of topics from women as translators, the gender of language and how translation can act as an effective tool for the betterment of life. Majority of the essays in the volume are crafted in lucid, easy to read language and require little or no background reading. 